\title{
China-U.S. Oil Rivalry in Africa
}

\author{
ZHAO HONG
}

\begin{abstract}
China is now the world's second largest oil-consuming country after the U.S. Its global efforts to secure oil imports to meet increasing domestic demand have profound implications for international relations in the Asia-Pacific region. China's rising oil demand and its external quest for oil have thus generated much attention. This paper looks at the possibility of China clashing with the U.S. and other Western countries over African oil interests.
\end{abstract}

Keywords: China, oil strategy, African oil, U.S., energy rivalry.

\section{The Changing Pattern of China's Oil Supply and Demand}

China was an oil-importing country after its founding in 1949. From 1950 to 1959 China's annual import of oil increased from 0.33 million tons mts/year to $3.33 \mathrm{mts} /$ year (Wang 2001). In the early 1960s when the Soviet Union ceased to provide assistance and oil to China, China experienced a serious oil shortage. This led to the exploration of Daqing oil field. Production began at the Daqing field in 1963. In 1965 the domestic output of China's crude oil reached $10 \mathrm{mts} /$ year or 97 percent of the country's oil needs (Wang 2001); China became self-sufficient in oil.

The year 1993 was the turning-point in China's oil import and export situation. China became a net oil-importing country. China's demand for oil doubled in the space of a decade increasing from 3.3 million barrels per day (bpd) in 1995 to 6.6 million bpd in 2005. This was almost equivalent to one third of U.S. demand (International Energy Agency 2006). From 2000 to 2005 China's energy consumption had risen 60 percent, accounting for almost half of the growth in world energy consumption. This situation prompted a fundamental reassessment of China's, and thus the world's, energy future. The IEA (International Energy Agency) has raised its China 2030 forecast by 1.2 billion tons of oil equivalent (a 63 percent upward revision). This is more than India's total projected demand for that year (Figure 1). Under this scenario China will account for 20 percent of global energy demand, more than Europe and Japan 
FIGURE 1 Forecasts of China's Energy Demand (mtoe)

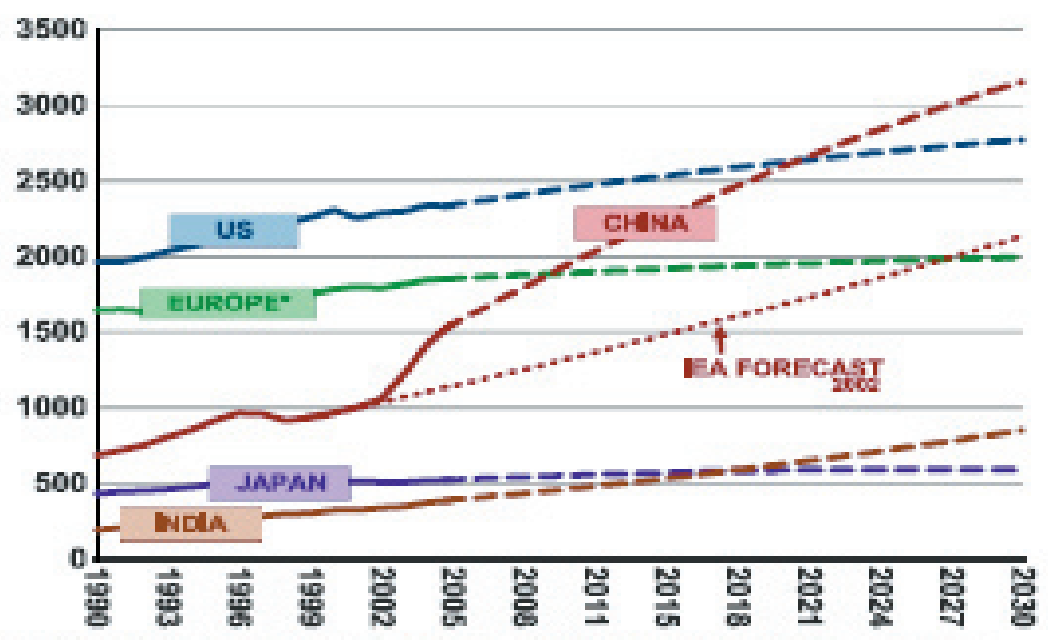

Source: ap statsicul Yearbooik 2006, IEA WEO 2002, IEA WEO 20ce. Excludes bicmass and waste. "Lunope refers to OCCD Curope.

combined and will easily surpass the U.S. as the world's largest energy consumer.Yet, China's domestic oil supply has failed to keep pace with this increasing demand and the outlook for a substantial increase in domestic production is grim. Most of China's oil fields have reached production plateaus or will soon decline in output (Gillboy 2002). Increased output from fields in Western China and offshore is likely to only slightly offset production declines in China's oldest and largest oil fields in the Northeast, including the Daqing field (Xu 2002).

The widening gap between China's domestic oil demand and supply indicates that it will be increasingly dependent on imported oil (Figure 2). Based on the demand and supply projections I have noted, China's oil imports are expected to increase from about 3 million bpd in 2005 to between 6 million and 11 million bpd in 2020, or some 60-80 percent of the country's total oil consumption (Downs 2006).

Today's oil market is characterized by increasing state ownership and rising resource nationalism. Approximately 85 percent of oil traded is controlled by state oil companies owned by host governments. Concession agreements, which used to be common, are now rare. Instead, producing states prefer to work with foreign oil companies. They tap the expertise, technical services and investment capital they offer. 
FIGURE 2 China's Oil Demand and Domestic Supply

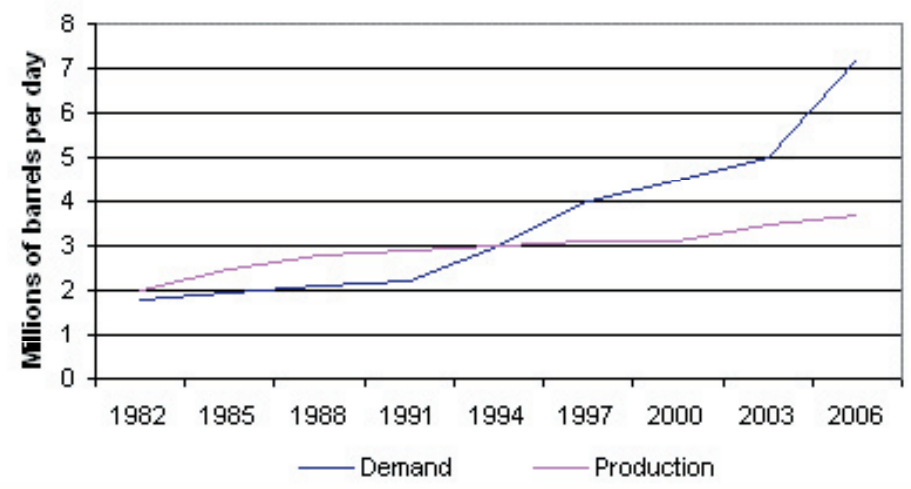

\section{China's 'Going Out' Strategy}

The dramatic increase in oil imports and increasing difficulties in securing an oil supply has aroused concern and has received attention from China's academic and policy-making communities. Chinese leaders realized that to participate in the global oil market China needs a secure oil supply and to build its capacity. As early as 1992 the central government put forward a strategic policy for developing China's oil industry 'using two sorts of resources (domestic and overseas) and markets'. On January 1, 2001, Chen Jin Hua, former director of Chinese National Planning Committee, advocated 'establishing oil fields abroad' (Chen 2001), or the 'going out' strategy.

China hopes to achieve two objectives with this 'going out' strategy. One is to encourage China's oil companies to follow in the footsteps of international oil companies in developing equity oil, ${ }^{1}$ and to look for income and rent from the upstream sector (exploration and production). The other is to create internationally competitive firms - especially in 'pillar industries' - which can compete with the world's leading corporations, both in China and abroad. The Chinese leadership believe that China's future oil strategy will be influenced by the growing strength of its oil companies. To be more competitive globally, Chinese oil companies need to compete with international firms in world markets. Meanwhile, the 'going out' strategy will facilitate the export of oil-exploration equipment and other goods and will create and promote bilateral trade between China and host countries. 
The decision to invest in oil exploration and production abroad was actually initiated by companies themselves. Among the three biggest Chinese oil companies,2 CNPC (China National Petroleum Corporation) was the first to venture overseas. CNPC began to set its sights beyond China's borders in the late 1980s and announced in 1991 that internationalizing its operations was one of its long-term strategies. It made its first overseas investment with the purchase of a stake in a United Nations sponsored oil sands development project in Alberta, Canada. In 1993 CNPC acquired the exploration right of Peru's Talara oil field paying US\$25 million (Zha 2005). From the later 1990s CNPC tilted its 'going out strategy' toward Africa.

Since the late 1990s, China's policies towards Africa have been closely linked to the objectives of its major state-owned company, CNPC. China had invested in 27 major oil and natural gas projects in 14 African countries by the end of 2005. China's oil imports from Africa have been increasing at an annual rate of 30 percent, slightly higher than that from the rest of the world (26 percent). China imports oil mainly from Angola, Sudan, Republic of Congo, and Equatorial Guinea, with Angola being the leading supplier of oil from Africa. In 2006 Angola accounted for 50 percent of China's oil imports from Africa and narrowly overtook Saudi Arabia to become China's top crude oil supplier (Reuters News 2006).

China has also benefited from its experience in Sudan. About 50 percent of China's equity oil comes from Sudan, and 65 percent of Sudan's oil exports go to China (Petroleum Intelligence 2006). The number of

FIGURE 3 China's Overseas Equity Oil Production and Imports, 2006

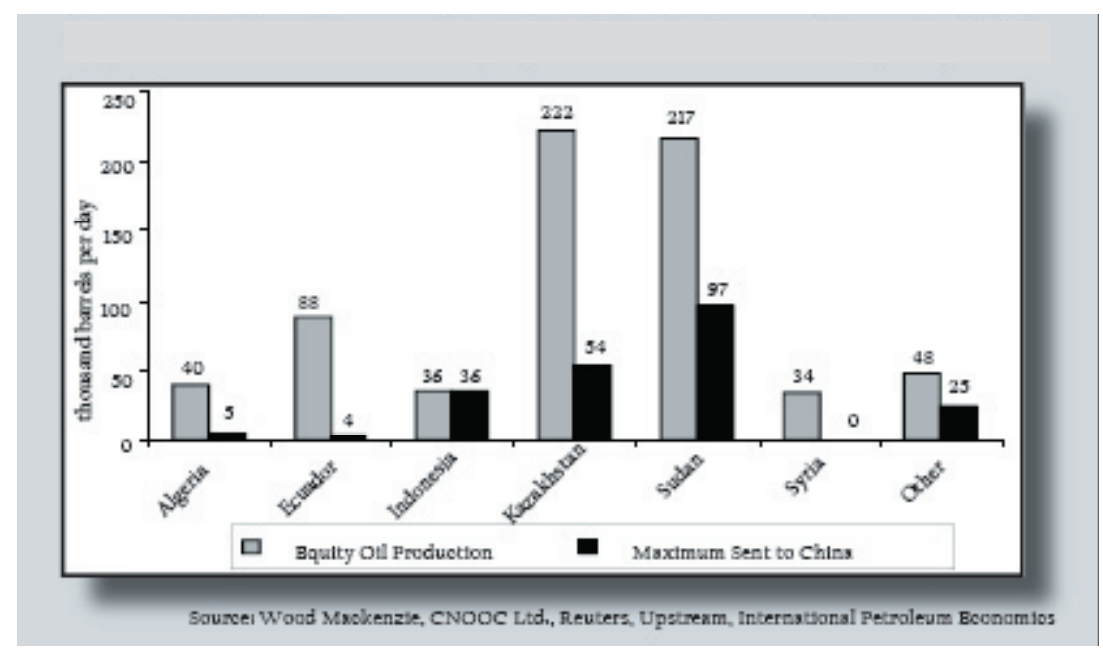


Chinese workers in Sudan has tripled since the early 1990s reaching 24,000 in 2006. Chinese non-oil investments are significant as well, including hydro-electric facilities, a new airport for Khartoum, and several textile plants. China also operates the vast bulk of Sudan's oil production and has a 50 percent stake in the nation's only major refinery in Khartoum (Lee 2007).

\section{Factors for China's Oil Companies Going to Africa}

The Persian Gulf and Asia-Pacific regions were China's main sources of imported oil in the 1990s. In 1995, these two regions supplied almost 87 percent of China's oil imports (Persian Gulf 46 percent, Asia-Pacific 41 percent). However, since the end of 1990s the importance of these two regions in China's oil imports has diminished. In 2006, the Asia Pacific's portion declined to 8 percent, while the Persian gulf's portion hovered at 45 percent (figure 3). The Asia Pacific region does not have the supply to meet China's oil import demand. Indonesia, the region's second

FIGURE 4 China's Crude Imports by Region

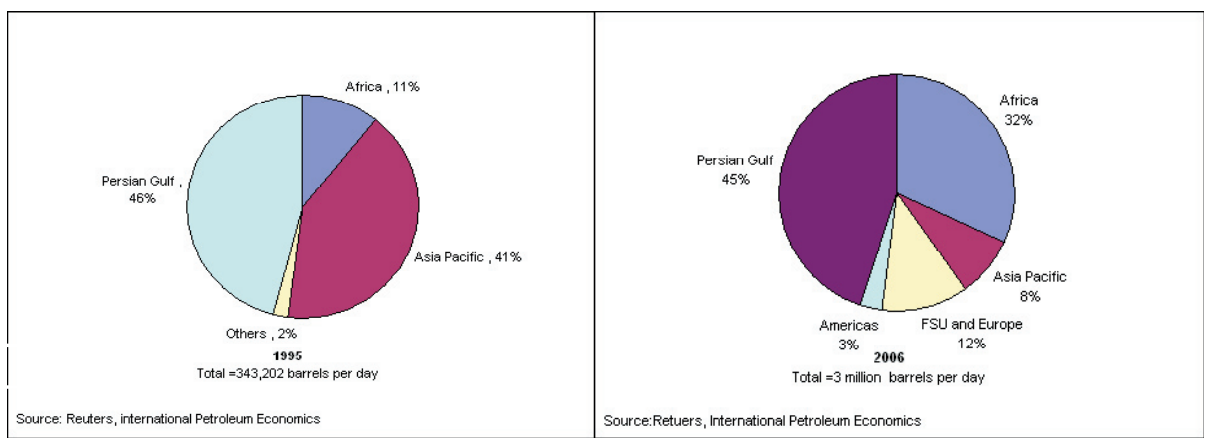

largest oil producer (behind China) and once China's largest supplier (31 percent in 1995), is now a net oil importer.

The Persian Gulf will remain an important source of crude oil for China. However, the 9.11 terrorist attacks on the U.S., the predominantly American 'war on terror' and the military interventions in Afghanistan and Iraq, have all heightened China's sense of insecurity and vulnerability. Beijing is concerned that Washington's reaction to the 9.11 terrorist attacks has further destabilized the already far from stable oil-producing regions of the Middle East and Central Asia. China has to diversify its energy import resources for the sake of oil security. China perceives the current oil production order and partnerships as entrenched. Over the 
past five decades U.S., Japanese and European companies have forged relationships with key producing countries. Southeast Asia was under the exclusive control of Western powers during the colonial period. The oil-producing territories of Indonesia, Brunei, Sarawak and Burma (Myanmar) were controlled by the Dutch or British. Western control and the head start of Western oil companies in exploration, development, transport, refining and petrochemical as well as natural gas industries had helped to entrench Western interests there. It would be difficult for Chinese oil companies to enjoy equal opportunity in those markets. Chinese oil companies felt compelled to find alternative sources of oil.

Africa is believed to be one of the main expanding sources of future global oil supply. The Wall Street Journal predicted that by 2010 'West Africa will be the world's number one oil source outside of OPEC' (Ball 2005). Africa's oil surplus has grown over the past decade and at the same time the light, sweet crudes of West Africa are well suited to China's refineries. Unlike the Middle East, African oil upstream markets are open to foreign investors. Europe and the U.S. have yet to monopolize some of these new oil producers, such as Sudan and Angola.

The U.S. influence and control over oil in the African region have been either weak or counterbalanced by political factors. Some African countries, such as Libya and Sudan, had been barred from U.S. energy investment and trade. In Libya's case, this was because of its support for terrorism and its pursuit of weapons of mass destruction. In Sudan's case it was due to egregious human rights behaviour. This situation provided China with a unique opportunity to establish a significant position in one of the few remaining underdeveloped oil regions of the world.

China is not a newcomer to Africa. China has been playing a significant role there for several decades becoming a major actor on the African scene in the 1960s and 1970s when, as part of its ideological rivalry with the Soviet Union, China supported certain national liberation movements (notably those that were prepared to eschew Soviet aid) and some friendly post-independence regimes. As part of this effort China provided arms and military equipment and helped build roads and railroads. 'Between 1955 and 1977, while many African countries were fighting for independence and self-determination, China sold US\$ 142 million worth of military equipment to Africans. Moreover, China opened its universities to over 15,000 African students for free education and has consistently supported Africa's development and responded to emergencies' (Klare and Volman 2006a). For this and other reasons, China cannot be considered as an interloper in Africa. China 
is a legitimate player with a credible history of supporting African development efforts.

Limited opportunities to raise domestic upstream production and thin margins on downstream activities ${ }^{3}$ is another factor compelling Chinese oil companies to scour the world for investment opportunities and untapped energy reserves. To grow an upstream business there are only two options: one is to explore somewhere more risky, the other one is to expand through mergers and acquisitions. Following CNOOC's aborted bid to acquire Unocal, Chinese firms see bigger risk in bidding for U.S. and European energy firms than in drilling for oil in Sudan, Syria, or Iran, where Western oil companies are either prohibited from investing or hesitant to do so out of fear of political risks.

Chinese oil companies are less concerned that a host country will one day decide to nationalize their assets. This is partially because these state-owned firms are new to the game and have yet to endure such an ordeal. They also face lower investment hurdles overall and can thus accept a higher risk premium. The case of CNOOC's attempted acquisition of Unocal in 2005 is well known. The smallest of the three Chinese oil majors was able to secure US\$ 7 billion in cheap state financing as part of its US $\$ 18.5$ billion bid (Rosen 2007). Another example is CNPC whose 2006 profits alone totalled US\$ 24 billion (Lee 2007). As CNPC is not required to pay dividends to the state and cannot find enough new outlets for investing the profits, the only alternative is to put the money into bank deposits. With less opportunity costs CNPC is more able to overcome various investment difficulties and can take on a higher risk level than BP or Chevron whose shareholders would rather take their money and reinvest it elsewhere if the company cannot deliver doubledigit returns (Rosen 2007).

Finally, the success of Chinese oil companies going into Africa should also be attributed to concession agreements from some African countries. With a dramatic fall in foreign direct investment (FDI) after the end of the Cold War, the introduction of Chinese FDI was welcomed. There is genuine enthusiasm on the part of African governments for providing concession agreements for Chinese entrepreneurs investing in their countries and opening new business in neglected sectors such as the oil industry.

China's Sudan project is a good example of the country's interest in African countries and African resources. Sudan's modern oil industry began in 1978. The American company Chevron began oil exploration in 1974 in the Muglad Basin. When civil war broke out for the second 
FIGURE 5 Sudan

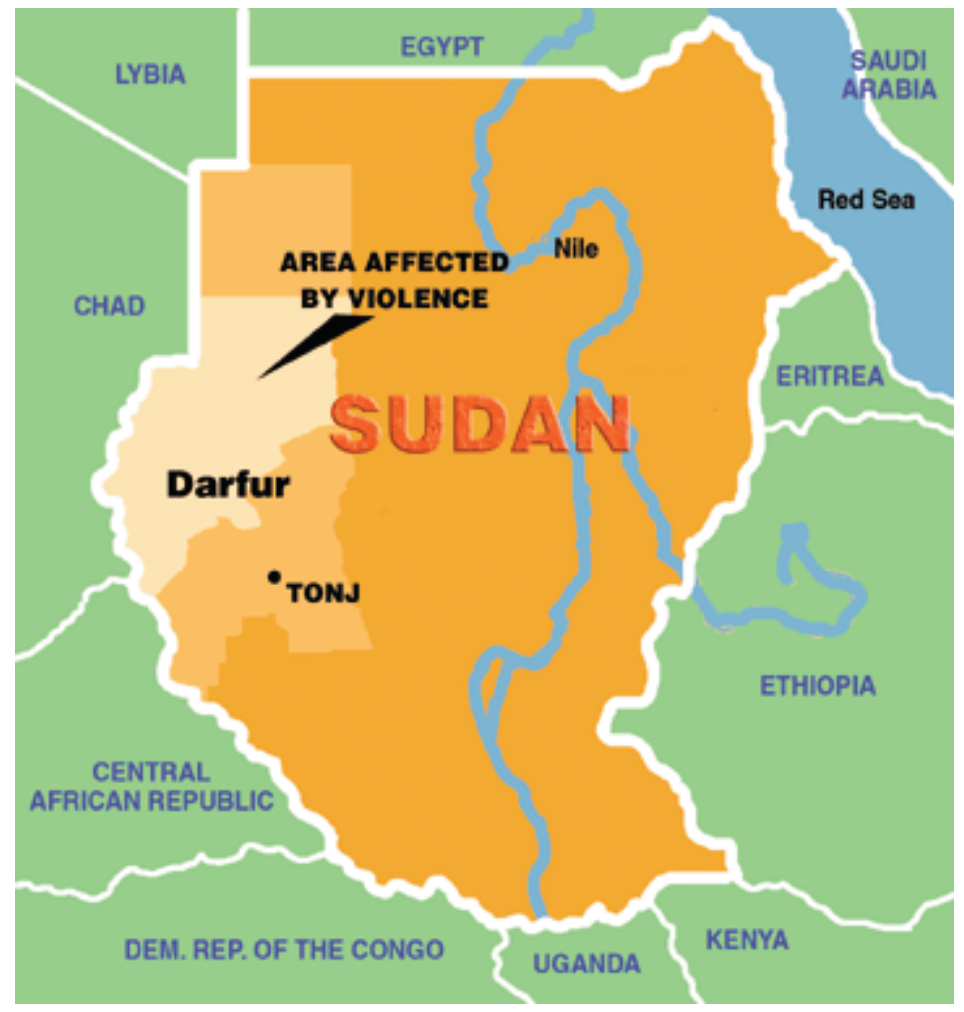

time in 1984 Chevron abandoned over one billion dollars of private investment and sold its interests to a Canadian firm which formed the Greater Nile Petroleum Operating Company (GNPOC). When Sudan's president Omar al-Bashir visited China in September 1995 he expressed the hope that Chinese oil companies could invest and explore oil resources in Sudan and so help Sudan to develop its own modern oil industry. CNPC conducted a preliminary study of Sudan and concluded that the fields in question were similar, in terms of geological formation, to China's Bohai Bay region. In 1997 CNPC decided to join an oil exploration project in Sudan and bought a 40 percent share from GNPOC. The goal of the newly formed company was to develop Sudan's oil field in the south-central part of the country and build a $1500 \mathrm{~km}$ pipeline to a coastal port facility at Marsa al-Bashair, near Port Sudan.

To support CNPC's business in Sudan, in September 1995 the Chinese government signed a framework agreement with the Sudanese government agreeing to provide a preferential line of credit amount- 
ing to Rmb 1.15 billion for oil exploration projects in Sudan (Lin 1997). After discussions with representatives from the Financial Ministry and Central Bank of Sudan it was agreed that credit would be provided to Chinese companies while the project would come under the supervision of the Sudan Bank. ${ }^{4}$ Sudan agreed to give China generous concession terms. These included no restrictions on profit reparations and exemptions from all domestic taxes on exported oil. The terms are among the most generous in the world. Thus from a purely commercial point of view, investment in Sudan was almost too good to turn down, especially given China's perception that most producing regions were tied to U.S., European and Japanese interests and might be less receptive to Chinese overtures.

\section{China's Energy Strategy in Africa}

China's oil venture in Africa has expanded over the last few years. Since 1999 crude oil imports from Africa have accounted for over 20 percent of total oil imports and in 2005 this percentage was increased to 31 percent (38.47 mts/year). In 2005 Angola, Sudan, Congo and Equatorial Guinea were among China's top ten oil importing partners, while other oil producing African countries such as Nigeria, Gabon and Cameroon are increasing their oil exports to China. The growing dependence on imported oil from the continent means that China will continue with its emphasis on Africa as part of its new energy strategy.

\section{Promoting energy diplomacy}

The Chinese government began giving financial support to African countries in the 1970s. At the outset the objectives of support were largely ideological in nature. With the advent of its economic reforms in 1978 the Chinese government stepped up its diplomatic aid to Africa and this assistance began to serve multiple purposes, including economic and oil objectives. In recent years the assistance has become both more sophisticated, in terms of the instruments utilized and more geographically diverse. In the 1980s the Chinese government provided much of its economic aid in the form of building large non-commercially oriented projects such as sports stadiums, hospitals, schools and government office buildings in Gambia and Sierra Leone, and other countries. In the 1990s, support began to shift to grants. Today, the proportion of non-commercial aid has been decreasing with commercially oriented loans accounting for the vast majority of Chinese government-sponsored African aid. 
China's Export-Import Bank, which was established in 1994 as a state policy-bank, is the sole state-owned entity the Chinese government uses to dispense official economic aid worldwide, including aid to Africa. According to the World Bank, as of 2005 the Chinese Export-Import Bank had made an accumulated commitment of US $\$ 800$ million in concession loans for 55 projects in nearly 22 African countries and as of mid-2006, the total amount of Export-Import Bank loans to Africa reached over US $\$ 12.5$ billion in infrastructural development alone (Gill 2007). These projects are mainly concentrated in oil-rich countries such as Angola, Mozambique, Nigeria, Sudan and Zimbabwe. In the summer of 2006 a US\$ 2 billion infrastructure loan was announced during Premier Wen Jiabao's visit to Angola as part of a seven-nation African tour (France 2006). When visiting Africa in early 2006 Chinese president Hu Jintao promised to provide preferential credit of US\$ 3 billion and that China would be a preferential supplier of credit amounting to US\$ 2 billion. He also announced that China's support for African countries would be doubled by the year 2009 (Financial Times 2006). China is also using debt relief to assist African nations. Since 2000, Beijing has taken significant steps to cancel the debt of 31 African countries. In 2000, China wrote off US\$ 1.2 billion in African debt and in 2003 Beijing forgave another US\$ 750 million (Broadman 2007: 275).

In past years developing bilateral relations with most African countries has been a priority for Chinese diplomacy. Most aid has been provided using bilateral channels. Now, as China becomes a greater player in Africa, it has begun cooperation with multilateral organizations. China has joined the 'Donor Coordination Groups' based in Kenya and Tanzania. China had also started cooperation with NEPAD (New Partnership for Arica's Development) in 2003. Development priorities in Africa were explicitly discussed with this group. China's role in the UN, its contributions to the African Development Bank, and the recent conference of African leaders in Shanghai, are testimony to China's evolving recognition that a strategy based on international cooperation may be more important than one that relies on special arrangements.

\section{Incorporating oil into a broader business regime}

Realizing that it did not have the historical linkages with key oil-exporting countries enjoyed by U.S. and European multilateral companies, China tried to approach Africa not simply as an oil resource base, but as part of a greater interdependent business relationship. By the end of 2005 China had invested in 27 major oil and natural-gas projects in 14 
African countries, including Angola, Sudan and Nigeria. China will now further increase its investment in Africa's oil through its state-owned oil companies. In 2006 CNOOC paid US\$ 2.7 billion to obtain a minority interest in a Nigerian oil field and US\$ 4 billion to build refineries in the same country and Sinopec has paid US $\$ 2.2$ billion for two oil fields in Angola (The Economist 2006). China has also been investing in related infrastructure. In Nigeria, China Civil Engineering Construction Corporation signed a US\$8 billion contract in October 2006 to build a 1,315 km railway line which will connect the commercial cities of Lagos and Kano with the oil cities of Jos and Port Harcourt. In terms of trade, from 2000 to 2005 bilateral trade between China and African countries increased by 40 percent on a year-on-year basis, reaching US\$ 36.3 billion in 2005 . To date China has established trade relations with all African countries with over 800 foreign trade companies doing business there.

China believes that modern international oil cooperation should be based on a 'win-win' principle. Beijing believes this is the best basis for sustainable development and enlargement of oil cooperation. In implementing its 'going out' strategy in Africa, for instance, CNPC focused on mutual benefits with resource countries. In the Sudan project nearly 50 percent of the revenue went to the Sudanese government. CNPC and its branches in Sudan have employed over 4000 Sudanese employees and over 7000 contract workers greatly relaxing the employment pressure in Sudan. Meanwhile, CNPC lays stress on training for its Sudanese employees. Since 1998 CNPC has spent US\$ 1.5 million on sending 35 Sudanese students to study at various universities in Beijing.

In developing its relationships with African countries China has deliberately avoided a single focus on oil supplies and has attempted to enlarge its range of economic exchanges. China's goal is to create a level of economic interdependence that will lead to greater trade, including the purchase of oil and gas supplies. By the end of 2006 China had established over 800 non-financial enterprises in Africa, with the accumulated value of investment reaching US $\$ 11.7$ billion. The investment projects cover trade, textile, power generation, road construction, tourism and communications. Strategically, these endeavours are meant to reinforce Beijing's efforts to establish itself in Africa as a desirable long-term customer for the continent's oil exports.

China is negotiating for the establishment of a regional economic free trade area with the Southeast African Customs Union and as I note above, China has joined the African Development Bank. China has also joined the Western African Development Bank and has built its more ex- 
pansive engagement in Africa within the FOCAC (Forum on China and Africa Cooperation) framework. The third FOCAC summit in Beijing in November 2006 stands out from the previous two (2000 in Beijing and 2003 in Addis Ababa) for its exuberance, scale and ambition. Meanwhile, China has established mechanisms, such as bilateral committees between China and African countries and political consultation between foreign ministries in order to conduct dialogue and consultation in a flexible and pragmatic manner. All these indicate that Beijing has launched a comprehensive and ambitious program aimed at courting Africa.

\section{Adjusting the approach to Africa}

Until last November China actively worked to block U.S. initiatives at the U.N. Security Council aimed at forcing Khartoum into allowing a more robust peacekeeping mission in its Darfur region. China has been careful not to endorse U.N. involvement in the domestic affairs of the host government without consent. This is a policy that arises from the fear that someday such a standard could be used against China's own interests. China believed that its activities in Sudan were commercial in nature, and doubted foreign intervention would bring democracy and justice to that troubled nation. Beijing noted that 'history has shown that oil-importing countries have little power to effect change in many of the world's oil states' (Zha 2006). However, as the Sino-African relationship has developed further, China has begun to alter this policy.

China's investment interest is now beginning to be jeopardized and harmed in Sudan and some other African countries. 'China is finding it more difficult to follow its non-interference policy in Sudan, while also ensuring the stability of its investments in the country's oil industry' (Wolfe 2007a). Indeed, Beijing does not believe that Khartoum's actions will lead to a resolution of the present crisis and this could potentially undermine China's investments and oil interests in Sudan. Beijing now believes that the only way to maintain stability in the region is for outside powers to force a negotiated settlement.

China started to adjust its approach in October 2006 when it voted in favor of a bigger UN peacekeeping presence in Khartoum. The larger force would buttress a weak African Union force on the ground. On his visit to Khartoum this February, Chinese President Hu Jintao told al-Bashir that 'Darfur is a part of Sudan and you have to resolve this problem' (Wolfe 2007b). In May 2007, China announced the dispatch of 275 military engineers to help strengthen the international presence 
in the country. China subsequently appointed Liu Guijin (former Chinese ambassador to South Africa and Zimbabwe) as China's special representative for African affairs, indicating that China is loosening its 'non-interference' policy in certain circumstances. However, there is little reason to believe that China will shift toward the isolation policy advocated by the U.S. In 2007 China held several meetings with Sudanese officials. They pushed for closer relations and a more 'flexible' approach to Darfur. In each meeting China used every opportunity to reassure Khartoum that it has not fallen out of favour with Beijing. ${ }^{5}$ In fact China's approach to solving the long-lasting conflict in Darfur has been to provide comprehensive development assistance, while finding every tactical means possible to persuade al-Bashir's government to comply with Western requests.

\section{Is China's Oil Venture Fuelling Rivalry with the U.S.?}

China's increasing oil investment in Africa has aroused the concern of some American officials. In the past few years another perceived threat has arisen: the possibility that China will pre-empt U.S. firms in the development of promising oil fields and compete with the U.S. for the loyalty of local governments. Although not all U.S. officials would put China in the 'threat' category with respect to African oil there is concern over the growing Chinese presence in the region among some in the U.S. Congress and the Department of Defence (DOD). For example, Representative Christopher Smith of New Jersey told the House Committee on International Relations in July 2005 that 'China is playing an increasingly influential role on the continent of Africa, and there is concern that the Chinese intend to aid and abet African dictators, gain a stranglehold on precious African natural resources, and undo much of the progress that has been made on democracy and governance in the last 15 years in African nations' (Klare 2006b). Another example is the view reflected in the DOD's 2005 report on Chinese military capabilities. The Report's authors note that China's role in African oil could affect U.S. policy. They recognize that 'China's growing reliance on imported energy, especially oil and natural gas, "is playing a role in shaping China's strategy and policy". Such concerns factor heavily in Beijing's relations with a number of major oil producers including Angola and Sudan. Beijing's belief that it requires such special relationships in order to assure its energy access could shape its defence strategy and force planning in the future' (US DOD 2005). This hints at the belief of 
the DOD that any such efforts on China's part could pose a challenge (even a direct challenge) to U.S. security interests. However, it does not necessarily follow that China's quest for oil is bound to lead to clashes over energy with the U.S. In truth, the U.S. and China are not really in direct conflict over many energy issues. Nevertheless, China's search for oil is creating a new rivalry with the U.S. over influence in Africa. If not managed prudently and properly, this rivalry might generate bilateral friction between the two big powers.

\section{U.S. policy on African oil}

Like China, the U.S. has exhibited an extraordinary interest in African oil. In the light of Africa's unique ability to increase its output in the years ahead, 'Africa is expected to be one of the fastest-growing sources of oil and natural gas for the American market' (Klare 2006a). It is predicted that within the next decade the U.S. will rely on Africa for 20 to 30 percent of its oil imports. Moreover, the Bush government has been seeking to enhance U.S. access to African oil in order to reduce its dependence on the ever-turbulent Middle East. U.S., oil imports from Africa in terms of total annual oil imports increased from 16 percent in 2000 to 20 percent in 2005, while China's rose from 24 percent to 30 percent (Table 1). In 2006, the U.S. imported 2.23 million barrels per day (bpd) from Africa, slightly higher than that from the Middle East (2.22 million bpd). Private-sector engagement is steadily rising concentrated in the energy field with annual two-way trade reaching US\$ 60.6 billion in 2005, up 36.7 percent from 2004 (Gill 2007). For the most part, the U.S. policy regarding African oil is aimed at improving the investment climate for American firms and strengthening the internal security capabilities of friendly governments. For instance, to enhance U.S. access to African oil the Bush government has sought to expedite the removal of obstacles to the participation of U.S. oil companies in Libya and Sudan. In February 2004, following a declaration by Libya that it would abandon its weapons of mass destruction and comply with the Nuclear Non-Proliferation Treaty, the White House eased sanctions on Libya and announced that 'U.S. companies will be able to buy or invest in Libyan oil and products'. This will happen in Sudan as well if a peace agreement between the northern government in Khartoum and the Sudanese People's Liberation Front takes hold and conditions improve in Darfur (Klare 2006a).

The U.S. defence establishment devoted relatively meager resources to Africa (in comparison with U.S. military expenditures geared to Europe, 


\begin{tabular}{|c|c|c|c|c|c|c|c|c|c|c|c|c|c|c|c|}
\hline 18 & 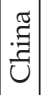 & $\begin{array}{l}1 \\
\infty \\
0\end{array}$ & $\begin{array}{l}\infty \\
0\end{array}$ & 市 & $\begin{array}{l}+ \\
\infty \\
\infty\end{array}$ & $\begin{array}{l}\text { in } \\
\text { in }\end{array}$ & $\vdots$ & $\vdots$ & $\begin{array}{l}\text { ì } \\
\text { i }\end{array}$ & ले & $\begin{array}{l}\text { రु } \\
0\end{array}$ & $\begin{array}{l}\text { Lी } \\
0\end{array}$ & $\begin{array}{l}\text { fे } \\
\text { क } \\
\text { ले }\end{array}$ & ণి & 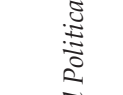 \\
\hline$\widetilde{N}$ & s & $\begin{array}{l}m \\
\text { ते } \\
\text { ते }\end{array}$ & స్ & $\begin{array}{l}\text { 今े } \\
\text { तें }\end{array}$ & $\stackrel{H}{\oplus}$ & $\begin{array}{l}\text { Ln } \\
\text { in }\end{array}$ & $\begin{array}{l}\text { ปี } \\
\text { : }\end{array}$ & $\stackrel{+}{\circ}$ & $\stackrel{+}{\stackrel{H}{N}}$ & ڤे & & $\stackrel{\circ}{\stackrel{+}{+}}$ & ت્) & ¿্. & \\
\hline 4 & 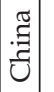 & $\begin{array}{l}\infty \\
0 \\
0\end{array}$ & $\vdots$ & तु & $\begin{array}{l}\stackrel{\text { Pq }}{\infty} \\
\dot{m}\end{array}$ & $\begin{array}{l}\stackrel{\infty}{\wedge} \\
\stackrel{+}{+}\end{array}$ & $\vdots$ & $\vdots$ & $\begin{array}{l}\text { ले } \\
\text { - }\end{array}$ & $\begin{array}{l}\text { भे } \\
\text { - }\end{array}$ & $\begin{array}{l}N \\
\text { in }\end{array}$ & $\begin{array}{l}\infty \\
\infty \\
0\end{array}$ & $\begin{array}{l}\text { क़े. } \\
\text { in } \\
\text { m. }\end{array}$ & নे & \\
\hline సి & s & $\overrightarrow{\vec{N}}$ & $\begin{array}{l}0 \\
0 \\
0\end{array}$ & $\begin{array}{l}\text { Lص } \\
\stackrel{2}{n}\end{array}$ & $\stackrel{\infty}{\oplus}$ & $\stackrel{\Lambda}{0}$ & $\stackrel{\circ}{\circ}$ & $\stackrel{H}{\rightleftarrows}$ & $r$ & 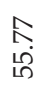 & & $\begin{array}{l}\text { ते } \\
\text { ले }\end{array}$ & $\begin{array}{l}\stackrel{0}{G} \\
ت\end{array}$ & $\begin{array}{l}\infty \\
\stackrel{\infty}{\sim}\end{array}$ & $\frac{5}{5}$ \\
\hline$m$ & $\mid$\begin{tabular}{|l|}
$\mid \mathfrak{\Xi}$ \\
: \\
\end{tabular} & $\stackrel{n}{\sim}$ & $\begin{array}{l}\infty \\
0\end{array}$ & $\ddot{\circ}$ & $\begin{array}{l}\text { \& } \\
\stackrel{-}{-}\end{array}$ & $\begin{array}{l}\text { ले } \\
\text { ले }\end{array}$ & $\vdots$ & $\vdots$ & $\stackrel{m}{\stackrel{2}{0}}$ & $\stackrel{1}{\stackrel{0}{0}}$ & กิ & $\vdots$ & $\begin{array}{l}\infty \\
\stackrel{a}{\Delta}\end{array}$ & 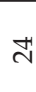 & \\
\hline$\tilde{N}$ & 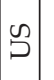 & $\begin{array}{l}3 \\
\infty \\
\infty \\
\infty\end{array}$ & $\stackrel{\mathscr{P}}{\mathfrak{0}}$ & $\underset{\overbrace{}}{\stackrel{1}{0}}$ & $\begin{array}{l}\text { N } \\
\text { ल }\end{array}$ & $\begin{array}{l}\text { in } \\
\text { in }\end{array}$ & $\begin{array}{l}\hat{\omega} \\
\text { ?े }\end{array}$ & $\stackrel{8}{\circ}$ & & $\begin{array}{l}\text { กิ } \\
\text { भ }\end{array}$ & & స్ & $\begin{array}{l}\infty \\
\dot{\alpha}\end{array}$ & $\hat{\imath}$ & \\
\hline$\checkmark$ & 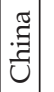 & $\vdots$ & $\vdots$ & $\begin{array}{l}\bar{\Lambda} \\
\text { เ }\end{array}$ & 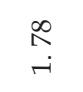 & $\begin{array}{l}\qquad 8 \\
\\
-1\end{array}$ & $\vdots$ & $\begin{array}{l}\stackrel{1}{\oplus} \\
0 \\
0\end{array}$ & $\vdots$ & भे & 胥 & $\vdots$ & $\begin{array}{l}\infty \\
\infty \\
\text { In } \\
\end{array}$ & तె & \\
\hline$\sim$ & s & $\stackrel{\Im}{\beth}$ & กิ & ֶֶ. & $\underset{\text { ָ̃ }}{\text { ה }}$ & ભુ & $\stackrel{\circ}{\circ}$ & Ș & & @̊. & & & $\stackrel{7}{8}$ & $\begin{array}{l}\infty \\
\stackrel{\infty}{\sim}\end{array}$ & \\
\hline$\delta$ & 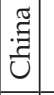 & $\vdots$ & $\vdots$ & $\begin{array}{l}\infty \\
\infty \\
\dot{\infty}\end{array}$ & $\stackrel{\stackrel{L}{\sim}}{\stackrel{i}{i}}$ & 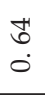 & $\stackrel{2}{\stackrel{2}{0}}$ & $\begin{array}{l}1 \\
\infty \\
0\end{array}$ & $\stackrel{\stackrel{L}{N}}{0}$ & $\begin{array}{l}\hat{N} \\
0\end{array}$ & $\begin{array}{l}\hat{\sigma} \\
\text { +i }\end{array}$ & $\vdots$ & $\begin{array}{l}\stackrel{L}{n} \\
\stackrel{\text { Mे }}{\longrightarrow}\end{array}$ & ন & \\
\hline$\widetilde{N}$ & D & 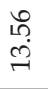 & ले & $\stackrel{\circ}{\circ}$ & 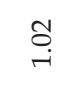 & $\begin{array}{l}m \\
\text { ते }\end{array}$ & $\begin{array}{l}1 \\
\infty \\
0\end{array}$ & $\begin{array}{c}\text { กै } \\
0\end{array}$ & & $\begin{array}{l}\text { İ } \\
\text { क् }\end{array}$ & & & $\begin{array}{l}0 \\
\infty \\
\infty\end{array}$ & 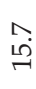 & \\
\hline ৪ & 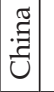 & $\vdots$ & $\stackrel{7}{\dddot{0}}$ & $\begin{array}{l}\forall \\
\infty\end{array}$ & ลू & 람 & $\begin{array}{l}\text { Li } \\
0\end{array}$ & $\begin{array}{l}\text { I } \\
0\end{array}$ & $\stackrel{m}{\stackrel{2}{0}}$ & $\begin{array}{l}\stackrel{9}{\vec{H}} \\
-\end{array}$ & $\vec{m}$ & $\vdots$ & 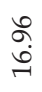 & 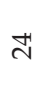 & \\
\hline 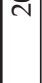 & s & $\stackrel{ }{\rightleftarrows}$ & $\begin{array}{l}\text { กิ } \\
\text { กे }\end{array}$ & $\begin{array}{l}\circ \\
\stackrel{1}{\circ}\end{array}$ & 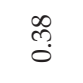 & $\begin{array}{l}\text { ก̂ } \\
\text { त }\end{array}$ & $\begin{array}{l}\delta \\
\text { d. }\end{array}$ & के & & $\begin{array}{l}\infty \\
\infty \\
\dddot{\gamma}\end{array}$ & & & $\begin{array}{l}\text { 0. } \\
\stackrel{\infty}{\infty}\end{array}$ & ڤે & \\
\hline I & 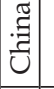 & $\vdots$ & ت् & $\begin{array}{l}\infty \\
\infty \\
i\end{array}$ & $\begin{array}{l}\vec{\infty} \\
0\end{array}$ & $\begin{array}{l}\infty \\
\stackrel{\infty}{0} \\
0\end{array}$ & $\begin{array}{l}18 \\
0 \\
0\end{array}$ & $\stackrel{\stackrel{L}{N}}{\circ}$ & $\stackrel{m}{\stackrel{0}{0}}$ & $\begin{array}{l}\hat{ल} \\
\text { - }\end{array}$ & $\begin{array}{l}\hat{N} \\
\dot{0}\end{array}$ & $\vdots$ & $\begin{array}{l}\stackrel{2}{N} \\
\stackrel{n}{n}\end{array}$ & ి & \\
\hline$\stackrel{-a}{\rightarrow}$ & so & $\begin{array}{l}\vec{\sigma} \\
\text { î }\end{array}$ & $\stackrel{10}{\stackrel{\longrightarrow}{-}}$ & 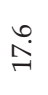 & $\stackrel{\overbrace{}}{0}$ & $\stackrel{\sim}{i}$ & $\underset{\infty}{\stackrel{\infty}{\infty}}$ & $\stackrel{\stackrel{L}{7}}{0}$ & & กै & & & $\stackrel{\circ}{\stackrel{+}{+}}$ & $\begin{array}{l}\stackrel{1}{\circ} \\
\stackrel{2}{n}\end{array}$ & \\
\hline 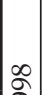 & 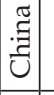 & $\vdots$ & 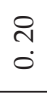 & $\begin{array}{l}F \\
ت\end{array}$ & $\begin{array}{l}\stackrel{N}{0} \\
0\end{array}$ & $\begin{array}{l}\infty \\
\stackrel{\infty}{0} \\
0\end{array}$ & $\vdots$ & $\vdots$ & $\stackrel{+}{ \pm}$ & $\begin{array}{l}\text { I } \\
\stackrel{0}{0}\end{array}$ & $\vdots$ & $\vdots$ & $\stackrel{\overbrace{}}{\vec{N}}$ & $\infty$ & 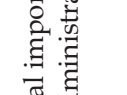 \\
\hline$\stackrel{2}{-1}$ & s & 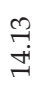 & î & 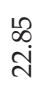 & $\ddot{\circ}$ & $\begin{array}{l}0 \\
i\end{array}$ & $\stackrel{-}{\circ}$ & $\begin{array}{l}\text { ते } \\
\vdots\end{array}$ & & ले & & & $\begin{array}{l}\circ \\
\text { +ా }\end{array}$ & $\begin{array}{l}\stackrel{0}{\infty} \\
\stackrel{\infty}{\sim}\end{array}$ & 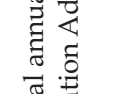 \\
\hline & 节 & $\vdots$ & సे & $\begin{array}{l}+ \\
\infty \\
\dot{\infty}\end{array}$ & $\begin{array}{l}\text { ते } \\
\vdots\end{array}$ & $\begin{array}{l}\infty \\
\sigma \\
0\end{array}$ & 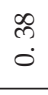 & $\vdots$ & $\begin{array}{l}\hat{0} \\
\dot{0}\end{array}$ & $\vdots$ & 0 & $\vdots$ & $\begin{array}{l}\sigma \\
\text { மn }\end{array}$ & $\stackrel{\curvearrowright}{\sim}$ & 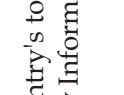 \\
\hline 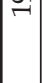 & D & $\begin{array}{l}\text { నे } \\
\stackrel{\text { ले }}{\rightleftharpoons}\end{array}$ & $\begin{array}{l}\vec{\infty} \\
-\end{array}$ & $\begin{array}{l}\infty \\
\stackrel{0}{0}\end{array}$ & స్ & $\stackrel{m}{i}$ & $\underset{ت}{\stackrel{H}{ت}}$ & $\begin{array}{l}\text { ปิ } \\
\vdots\end{array}$ & & $\begin{array}{l}\text { ठ } \\
\text { ले }\end{array}$ & & & $\begin{array}{l}\infty \\
\text { هె }\end{array}$ & $\underset{\sim}{\mathcal{I}}$ & 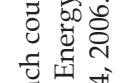 \\
\hline & & $\begin{array}{l}\stackrel{\pi}{\vec{\nu}} \\
\frac{\infty}{<} \\
\end{array}$ & 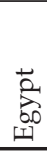 & 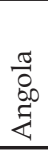 & 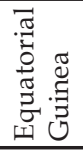 & \begin{tabular}{l}
0 \\
\multirow{0}{0}{} \\
0
\end{tabular} & $\begin{array}{l}5 \\
0 \\
0 \\
0 \\
0\end{array}$ & 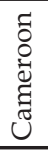 & $\stackrel{\pi}{\overparen{2}}$ & 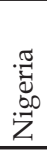 & $\begin{array}{l}\frac{E}{0} \\
\frac{0}{2} \\
\text { की }\end{array}$ & 疋 & 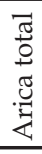 & ১o & 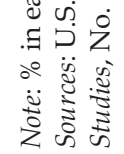 \\
\hline
\end{tabular}


Asia and the Middle East). As a result of growing American reliance on African oil and the uncertain security climate (partly due to China's growing influence there) in the region, the U.S. Department of Defence is now paying closer attention to Africa. The largest portion of U.S. aid to Africa is being directed to Angola and Nigeria, the leading African oil suppliers to the U.S. Total U.S. security aid to these two countries in the fiscal years 2004-2006 amounted to some US\$ 180 million. This is a substantial increase over the previous three-year period. U.S. military engagement in Africa has expanded significantly, especially in the Horn of Africa, the Sahara/Sahelian zone, and the Gulf of Guinea maritime zone. Most of the U.S. operations there are directed against terrorism, but the longer-term issue is still oil, especially in relation to China (Rogers 2007).

\section{Reducing China-US Oil Rivalry in Africa}

It is possible for China and the U.S. to confront each other over oil in Africa. China's increasing oil investment and trade breakthrough with Sudan obviously clashes with the U.S. and its allies' sanctioning of Sudan. After all, 'Chinese investments and trade will increase the host government's coffers, giving it the ability to buy more arms' (Lee 2007). Foreign policy analysts in Washington warned that 'Beijing's strategy of "locking up" the world's remaining oil supplies through long-term purchase agreements and aggressive diplomacy could lead Washington and Beijing into a struggle which is described as the 'geopolitics of oil' (Business Times Singapore 2007). Hence, American fears are unfounded. While CNPC dominates the oil sector in Sudan, China's National Oil Companies (NOCs) are minor actors among foreign investors. They lag far behind the International Oil Companies (IOCs) in terms of asset value and production. The commercial value of the oil investments in Africa of China's NOCs is just 3 percent of all company investments in African oil. China's NOCs also produce less oil and gas in Africa than most IOCs. In 2006 the total African output of the China's NOCs was only about one-third of that produced by the largest foreign producer in Africa-ExxonMobil. Although China's NOCs have enough capital, they lack the technology necessary to compete with IOCs such as BP, ExxonMobil and Shell. This is the case when it comes to some of Africa's most desirable blocks including those located in the deep waters of the Gulf of Guinea.

Undoubtedly China has been paying costs and even running a risk in its oil-related diplomacy in Africa. China has been criticized for doing 
FIGURE 6 Commercial Value and Production in Africa
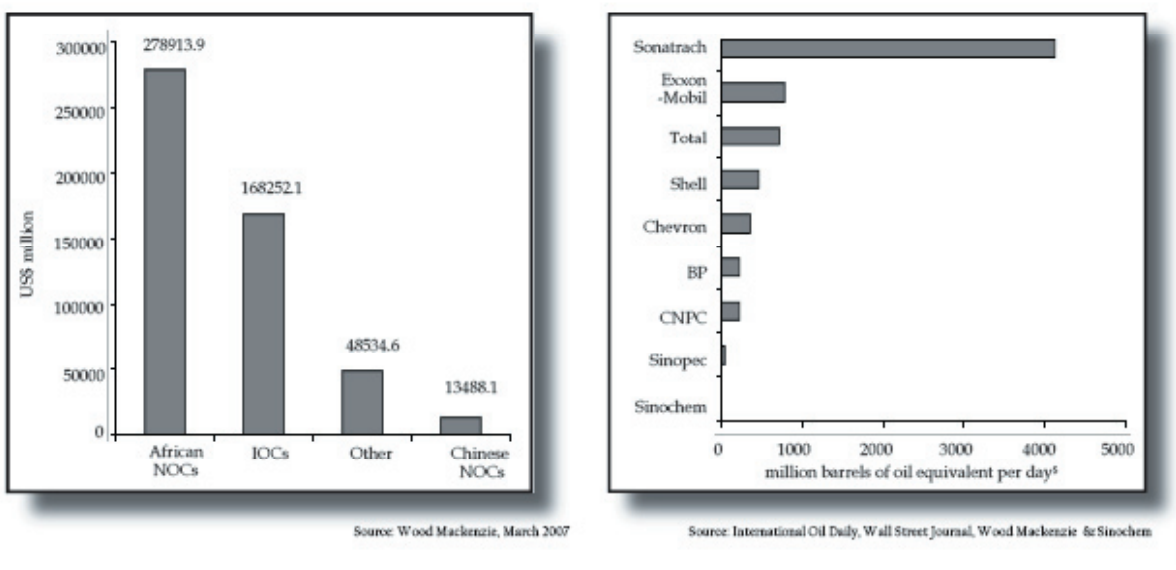

business with 'rogue states' and labelled as being engaged in a 'new colonialism to plunder resources'. The benefits of having relatively uncontested access to oil supplies may be worth the short-term political costs, but these costs will rise as China becomes more involved in the international market and they may affect the country's credibility in regional and international forums.

One of the arguments for China's oil investment in Africa is that acquiring oil through direct investment can provide domestic consumers with a more secure and less expensive supply of oil than the international market. The idea that equity oil enhances energy security is prevalent among some Chinese officials. However, it seems that the case of Sudan cannot efficiently support the belief that equity production by China's oil companies abroad can guarantee China a supply of oil that is more reliable and less expensive than the international market. In the case of Sudan, the Khartoum government has claimed that concession terms given to CNPC in the late 1990s were overgenerous and there is growing talk of renegotiating existing contracts. Meanwhile, the government in the South said that it had no interest in dealing with Chinese companies. ${ }^{6}$ In addition, the Khartoum government has initiated negotiations with Indian Oil and Natural Gas Corporation with the intent to sell a portion of its stake in the Greater Nile Petroleum Operating Company and has unofficially agreed to sell two new blocks, one to the Romanian company Rompetrol, and the other to the Algerian national oil and gas company, Sonatrach. It seems that the Sudanese government is looking for benefit-balance among foreign investors and that China's position of exclusivity is deteriorating. 
Based on the above assessment, China cannot take it for granted that Sudan and other African countries will repay China's oil interests for China's restraint in not condemning the conduct of the Khartoum regime. China has invested a large amount of capital with the expectation that over a long period of time it will get its money back plus a generous rate of return. In case these concessions are renegotiated or expropriated by the Sudanese government or its successors, China may find that the net value of its returns is far lower than anticipated. Beijing has already realized this and doubts whether equity production by China's oil companies, as small as it is, can greatly increase the country's energy security. If not, why endure the damage to China's image and risk the potential conflict with the U.S.? This thinking has led China to adjust its approach to Sudan.

China's strategy is 'one of humanitarian and development aid plus influence without interference, in contrast to the West's coercive approach of sanctions plus military intervention' (Qian 2007). Through high-level diplomacy, such as Chinese President Hu Jintao's visit to Sudan in 2007 and the dispatch of special envoys and multilateral platforms such as the United Nations and the China-Africa summit, China has been making tactical moves to press the Sudanese government to comply with the international community's requests.

To prevent the potential for conflict from becoming a self-fulfilling prophecy it is important for China and the U.S. to improve mutual understanding and expand coordinative relations with each other. Politically, China needs to do more than sending peacekeeping troops to Sudan. China needs to be more positive in responding to U.S. complaints. Repeating 'noninterference in domestic affairs' as its guiding principle for foreign affairs (China still insists so orally at least) is inadequate. Economically, Chinese companies could lead the way by giving business opportunities to their US partners in markets where Chinese companies have better political access. More importantly, China's decision makers need to keep in mind that energy security is a global issue and in an era of globalization a single nation's policy no longer works well in addressing oil security. In the future years a strategy based on international cooperation may look more attractive than one based on special arrangements with a few rogue states.

As far as the U.S. response is concerned it is essential to see that both sides share the same view on many controversial issues and understand China's situation. As the U.S. President's special envoy to Sudan said, 'Our policy and Chinese policy (on Darfur/Sudan) are closer than I 
realized they were and I think the Chinese are going to play an increasingly important role in helping us to resolve this. I think the visit was a very successful one because we found many more areas of common agreement, both about our objectives and our strategies for achieving those objectives' (Natsios 2007). The two sides have obviously become deeply intertwined economically and have a joint interest in managing their political relationship in a way that assures continued bilateral economic and oil interests in Africa.

China's political influence in Darfur should not be overestimated. At the same time as Beijing's investment in Sudan provides economic leverage, it also makes Beijing a hostage. China's role is limited. It will lose its credibility and influence if it overreaches its will politically because 'the effective influence that Beijing can exert over the Darfur crisis lies in its delicate balance between practicing an influence-without-interference strategy and maintaining the hard-won trust of the Sudanese government' (Qian 2007).

It is evident that China's oil investment in Africa is not a threat, but something to be encouraged. It has enlarged the availability of oil in the world market. For instance, China's investments and technical assistance in Sudan have helped turn the country into an oil exporter.

The U.S. can play a role in leading China onto the right track by, for instance, taking China into the IEA. ${ }^{7}$ This would turn China's unilateral energy policy into a multilateral one. In other words, it is essential for China to be further integrated into the global oil market by being

FIGURE 7 China's Sudanese Oil Production and Imports

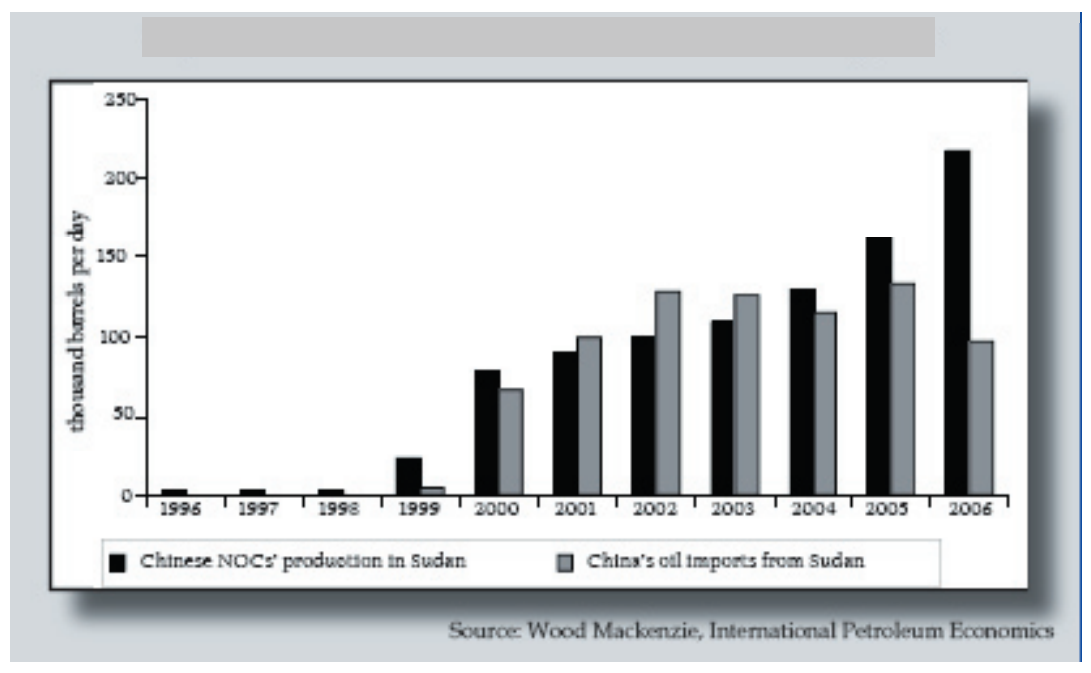


provided with an opportunity to participate in decisions on the 'rules' governing that market and sharing information on world oil market. China also wants to be assured that its oil interests will be protected in the event of turbulence.

\section{Conclusion}

As China's engagement in Africa expands economically and politically, Beijing continues to focus on Africa as a vital part of the country's energy strategy. At the November 2006 summit, China announced that over the period of 2007-2009 it will establish a US\$ 3 billion preferential loan package and a US $\$ 2$ billion preferential buyer's credit for African countries. It will also double aid to Africa, cancel all debts owed by African countries that were due in 2005, and establish a US\$ 5 billion China-Africa Development Fund to provide start-up capital to Chinese companies investing in Africa. But China's activities in Africa have still met with unexpected straits and difficulties. Although China's investment in Africa has now been diversified and China's business strategy in Africa has gone far beyond oil and other energy resources, China's investment has still been labelled by some Western media as 'new colonialism to plunder resources'. Some Western media reports and concerns have not only badly affected China's positive image in Africa, but have also made China's oil interests vulnerable to international pressure.

An example of the above concerns American jurisdiction over companies listed on the U.S. Stock Exchange. An interpretation of the Alien Tort Claim Act was used by human-rights groups to pressure the Canadian oil company Talisman Energy to sell its 25 percent share in GNPOC (Greater Nile Petroleum Operating Company). The share was sold in March 2003. CNPC was very interested in a listing on Wall Street, and submitted its application in 2000. A listing was expected to raise US $\$ 10$ billion. However, publicity generated by human-rights activists forced a withdrawal of CNPC. CNPC had no choice but to create a subsidiary, PetroChina, that explicitly denied that any of the capital raised would go to Sudan. In the end, only US\$ 300 million was raised (Alden 2005).

China no doubt has its own interests in Africa, but its engagement there takes into account the interests of African countries and their desire to first of all promote economic development. China has provided African countries with some urgently needed aid including concession loans and infrastructural development - bridges, roads, dams and power plants. However, China has not had due credit for its activities. China 
needs to consider further reforming its methods for supporting African countries and could help them find a new development model. Donations can relieve some urgent needs, but they cannot eradicate the roots of poverty and underdevelopment in African countries.

China's economic reform and development can be an example for Africa. China's financial system has played an effective role in developing its own undeveloped areas. China's reform experience in other fields including relatively advanced technology and some cultural aspects could also be emulated by African countries. China, as a leader in economic reform, can transfer its expertise in creative development to African countries. This would bolster China's image as a constructive and positive partner rather than as a colonial power out to plunder resources.

In short, by improving its activities and image as a donor China could change Western perceptions of its behaviour in Africa and this would greatly reduce potential conflicts with the U.S. Both China and the U.S. are becoming increasingly dependent on imported energy. As such, they are finding more common interests with regard to oil issues in Africa. Both hope to see political and social stability in Africa and a stable supply of oil at a fair price on international markets. They have the foundation and reason to turn oil and energy in general into an exercise in confidence building between them.

Dr Zhao Hong is Professor, Research School of Southeast Asian Studies, Xiamen University, Xiamen, China.

\section{NOTES}

1 Equity oil refers to standard industry production sharing agreements where the foreign oil company is given the right to sell a specified share of the oil produced. By early 2005, China's total secured equity oil was around 400 thousand barrels per day. This was equivalent to roughly 15 percent of China's total crude imports (while it makes up over 40 percent of U.S. oil imports) or 6 percent of China's current oil consumption. (http://ksgnotes.harvard.edu./research/wpaper.nsf/rwp/PWPOT017/\$File/rwp-07.017.lee.pdf)

2 CNPC was incepted in 1988. It is an offshoot of the Ministry of Petroleum Industry, with business operations mainly in the North and the West of China. Sinopec (Chinese National Petrochemical Corporation) was established in 1983 after merging assets from the Ministry of Petroleum Industry and the Ministry of Chemical Industry. Its stronger presence is in the South and East. CNOOC (China National Offshore Oil Company) was formed as a corporation under the Ministry of Petroleum Industry in 1982. It focuses on offshore investments.

3 For fear of passing inflation to an increasingly automobile-oriented and vocal middle class, as well as to low-income farmers and taxi drivers, China has to tightly control the gasoline and diesel prices. 
4 In 1994 China began to reform and changed the forms of its foreign aid, combining foreign aid with investments, trade and other bilateral cooperation projects (including energy cooperation).

5 When visiting Khartoum in February $2007 \mathrm{Hu}$ Jintao provided al-Bashir with an interest-free 100 million yuan loan to build a new presidential palace. He also wrote off another 70 million yuan in debt.

6 The two sides in Sudan signed a peace treaty in 2005-the Comprehensive Peace Agreement. Under its terms the South has a six-year period of autonomous selfrule. The South has formed its own oil company-Nilepet, but disputes are already emerging about which side has the right to grant concessions for future oil exploration. (Henry Lee and Dan A.Shalmon. 'Searching for Oil: China's Oil Initiatives in the Middle East', Faculty Research Working Papers Series, March 2007. Available at: http://ksgnotes.harvard.edu./research/wpaper.nsf/rwp/PWPOT-017/\$File/rwp07.017.lee.pdf)

7 In the near future China is unlikely to join the IEA, which requires membership in the OECD (Organization for Economic Cooperation and Development) and the maintenance of emergency oil stocks equivalent to at least 90 days of net oil imports.

\section{REFERENCES}

Alden, C. 2005. 'China in Africa'. Survival 47(3), Autumn.

Ball, J. 2005. 'Angola Possesses a Prize as Exxon, Rivals Stalk Oil'. Wall Street Journal, 5 December.

Broadman, H. G. 2007. Africa's Silk Road: China's and India's New Economic Frontier. Washington D.C.: World Bank.

Business Times Singapore 2007, 'China's energy policy is no threat, 24 May

Chen, Jin Hua. 'Oil Strategy and China's Energy Policy'. Journal of Chinese Petroleum, 2001 (2).

Downs, E. 2006 .'Energy Security Series: China'. The Brookings Foreign Policy Studies, December. Available from: http://www.brookings.edu/fp/research /energy/ 2006china.htm

Demongeot, M. and J. Hua. 2004. 'Analysis-No let up seen yet for China sweet crude imports'. Reuters News, 12 November, Factiva.

Financial Times 2006. 'Friend or Forager?', 23 February.

Financial Times 2006, 28 December.

France, B. 2006. 'China Makes Headway in Angola with Multiple Trade Ties'. Dow Jones International News, 30 November.

Gillboy, G. 2002. 'China's Energy Security Policy After September 11: Crossing the River When the Stones Are Moving'. CEAR Private Report, February 2002

Gill, B., Chin-hao Huan and J. S. Morrison. 2007. 'China's Expanding Role in Africa'. CSIS (Center for Strategic and International Studies) Report, January 2007. Available from: www.csis.org

International Energy Agency, Monthly Oi Market Report. 13 June 2006, p.49

Klare, M. and D. Volman 2006a. 'America, China \& the Scramble for Africa's Oil'. Review of African Political Economy No.108:297-309, ROAPE Publications Ltd., 2006

- 2006b. 'The African 'Oil Rush' and US National Security'. Third World Quarterly 27(4): 609-628.

Lee, H. and D. A. Shalmon 2007, 'Searching for Oil: China's Oil Initiatives in the Middle East'. Faculty Research Working Papers Series, March 2007. Available from: http:/ / ks- 
gnotes.harvard.edu./research/wpaper.nsf/rwp/PWPOT-017/\$File/rwp-07.017. lee.pdf

Lee,W. 2007. 'CNPC Earned \$ 23.85 Billion Profit in 2006, up 5.7 percent'. Platts Oilgram News, 24 January

Lin, M., 1997. 'Reform and Practice of Foreign Aid'. International Economic Cooperation, $1997(11)$

Natsios, A. U.S. president's special envoy to Sudan, speaking at a press briefing before departing Beijing on 12 January 2007

Petroleum Intelligence Weekly, 'China's CNPC Targets Overseas Integration Deals', 23 January 2006

Qian, J. and A. Wu 2007. 'Playing the blame game in Africa', International Herald Tribune, 23 July.

Reuters News, 'Why is China chasing African oil?' 3 November 2006.

Rosen, D. H. 2007. 'China Energy'. Peterson Institute for International Economics, May 2007.

Richardson, M. 2007. 'China-Sudan Ties: Beijing walks a tightrope'. The Straits Times, May 23.

Rogers, P. 2007. 'The United States, China and Africa: eyes on the prize'. Japan Focus, 21 March.

The Economist, 'China in Africa: Never too late to Scramble', 26 October 2006

US DOD, Office of the Secretary of Defense. 'The Power of the People's Republic of China'. Annual Report to Congress, Washington, DC: DOD, 2005, p10.

Wolfe, A. 2007a, 'China Adjusts its Approach in Africa'. The Power and Interest News Report, 5 February. Available from http://www.pinr.com/report.php?ac=view_ report\&report_id=613

- 2007b. 'China Claims Success on Darfur'. The Power and Interest News Report, 24 April. Available from http:/ / www.pinr.com/report.php?ac=view_report\&report_ id=643\&languag

Wang Jia Shu 2001. Petroleum and National Security. Beijing Earth Quack Press, p.155.

Xu Yihe 2002. 'China Energy Watch: Onshore Depletion Problems Loom'. Dow Jones Energy Service, 2 April.

Zha Daojiong 2005. 'China's Energy Security: From the Perspective of International Relation'. Review of International Economics, 12 November.

Zha, Daojion 2006. 'An Opening for U.S.-China Cooperation'. Far Eastern Economic Review, May 2006. 